activities which they have to direct, but is, from Secretary Walcott downwards, managed by men who have received their training in the field or the laboratory or the museum; men who are familiar with the needs and difficulties of their assistants; men who combine high ideals with a clear appreciation of what is practicable, and so carry out a consistent policy.

A feature of the National Museum, as of other American museums, is the large amount of exploration undertaken. An expedition, including collectors and kinematographers, is now at work in Africa. Mrs. Purdy Bacon has bequeathed fifty thousand dollars to establish a travelling scholarship for the study of faunas outside the United States. Many other expeditions are here reported on. But we would chiefly emphasise the policy of sending out the officers of the museum to study and collect. The whole of the geological staff was thus employed during the field-season of I9I8, filling gaps in the collections, obtaining specimens needed for public exhibition, and taking photographs to illustrate the explanatory labels. Many of the other departments also had members in the field.

Among other signs of life and growth, the report records the inauguration of popular scientific lectures, and the introduction of a Bill to provide a museum of history and of the arts as a memorial to Theodore Roosevelt. The building would afford much-needed space for the rapidly extending National Gallery of Art.

\section{The Religion and Origin of the Hawaian People.}

THE sixth volume of the Memoirs of the Bishop Museum at Honolulu ${ }^{1}$ continues the publication of Judge Fornander's literary collections. The first portion contains two important papers by native writers on the religion of the Hawaians. One, by Kamakau, contributed to the collection by Dr. W. D. Alexander, describes certain ancient ceremonies of which the principal are those connected with the prenatal development of the royal child, the direction of services to the gods, the catching of the fish opelu, and the feasts of the year. There are shorter notes on heathen prayers and the ceremonial erection of the heiau or god's house. A much longer paper by the Hawaian author, S. N. Haleole, deals with the functions of the Kahuna, "the priesthood called the Order of Sorcery." The word in varying forms (tahuna, tahunga, tauna) is used throughout the Eastern Pacific to denote persons possessed of varying degrees of wisdom from priesthood to sorcery, but in the west, in Tonga and Samoa, has become entirely secularised, and there (in the form tufunga) means nothing more than a carpenter or skilled workman.

The Kahuna in Hawaii was properly trained for his office, and gave evidence of his powers by divination from pebbles, clouds, shadows, and dreams, and by his magical effects with the maunai or cast-away portions of nail, hair, tooth, or clothing. His services were in request in times of war and threatened evils, for house-building or loss of lands, in courtship and medicine. The omens of agriculture, canoe-making, and fishing, with descriptions of the occupations themselves, are fully described.

The second part of this volume contains Fornander's speculations on the "Source and Migrations of the Polynesian Race." This appears somewhat out of date in the present stage of linguistic study.

1 Memoirs of the Bernice Pauahi Bishop Museum of Polynesian Ethnology 1 Memoirs of the Bernice Paua. Nos. I and 2. "Fornander Collection of
and Natural History. Vol. vi., Nos." Third Series. Parts $x, 2$. Pp. 358. Honolulu : H. I. Bishop Museum Press, 1919.) No. 2646 , vOL. 105]
The author regards India as the original home of the Polynesian people, and supposes that the Polynesian and Aryan language families separated before the latter had developed their inflected form, and that traces of Polynesians are found in the Malay Archipelago. A majority of the immigrants are thought to have passed through Torres Straits to the Loyalty Islands, and thence to Fiji, Samoa, and Tonga. Fornander's so-called evidence is very unsatisfactory. It is based mainly on the casual resemblances of certain Indian words to Polynesian, the Polynesian meanings being read into the Indian word or vice versa.

The theory of an Indian origin of Polynesian may be seen to underlie the theories of Macmillan Brown, Percy Smith, Christian, and Churchill, but certainly lacks the support bf sound linguistic evidence. According to this view, everything east of India which agrees with modern Polynesian is borrowed from an ancient form of Polynesian speech, though the languages themselves prove that Polynesia has received many of its words from primitive Indonesia, and that not by one migration, from one place at one time, but in severa! colonisations from various parts of the archipelago at different times.

The final portion of part 2 contains other papers by Fornander on Hawaian tradition, history, and genealogy.

As all the native writings in the first part are in the original Hawaian with translations, they form a considerable body of text which will be useful to the student of the language, quite apart from their value in the exposition of Hawaian religion. The whole work is very clearly and tastefully printed and a credit to the Museum Press.

SidNey H. Ray.

\section{Soil Temperatures. ${ }^{3}$}

THE pảper by Messrs. West, Edlefsen, and Ewing referred to below is an attempt to predict the probable temperature of any hour of any day. If the mean monthly temperatures of any place are known from previous records, it is possible to represent them by a Fourier series of the form

$\mathrm{T}=a+b \cos (\theta-c)+d \cos 2(\theta-e)+f \cos 3(\theta-g)+\ldots$ where $\mathrm{T}=$ temperature at time $\theta, a=$ mean annual temperature, $b, c$, etc. $=$ constants. It is also found for normal days that the temperature at any given hour is a certain percentage of the mean daily temperature, and that this percentage is practically constant irrespective of season. The Fourier series is used to predict the mean daily temperature, which is then multiplied by the appropriate percentage factor to obtain the temperature at the given hour. An arithmetical method, avoiding the use of the Fourier series, is also described. The results are fairly trustworthy for arid regions, but not for humid areas where storms, etc., are frequent.

In Capt. Franklin's third paper on soil temperatures (see "Forecasting Frosts," Nature, January I, 1920, p. $\left.45^{\circ}\right)$ the variations in the ratio of temperature ranges at the 4 -in. depth and the surface, $\left(\frac{R_{4}}{R_{0}}\right)$, are studied under a variety of weather conditions. The values vary widely, from 0.19 in a very dry soil to 0.85 during heavy rains. The most common value is about 0.40 . The influence of the soil-water on tem-

1 "Determination of Normal Temperatures by Means of the Equation of the Seasonal Temperature Variations, and a Modified Thermograph Record." By F. L. West, N. E. Edlefsen, and S. Ewing. Jown. Agric.

Res., vol. xviii. (Igzo), p. 499 . Franklin. Proe. Roy. Soc. Edinburgh, vol. xl. (1920), p. 56. 